\title{
Learning Environment and Motivation in Junior High School
}

\author{
Try Susanti ${ }^{1}$, Damris $^{2}$, Maison $^{2}$, Tanti $^{1, *}$ \\ ${ }^{1}$ Faculty of Teaching and Education, Universitas Islam Negeri Sultan Thaha Saifuddin Jambi, Indonesia \\ ${ }^{2}$ Faculty of Teaching and Education, Jambi University, Indonesia
}

Received February 29, 2020; Revised April 8, 2020; Accepted April 19, 2020

Copyright $\mathrm{C} 2020$ by authors, all rights reserved. Authors agree that this article remains permanently open access under the terms of the Creative Commons Attribution License 4.0 International License

\begin{abstract}
Purpose: Students' learning environment and motivation are important to the students in learning. Especially with 21 st century learning, students are required to be more active in learning than teachers, therefore the study aims to know if there is an influence between the learning environment and the motivation of students. Methodology: Using Mixed Methods. Where, the number of samples in the research was as many as 725 students from Madrasah Tsanawiyah in Jambi city using the purposive sampling technique. Analyzing data uses the application to obtain inferential and descriptive statistics. Finding: The results of this study are dominant in both the motivation and learning environment of students. This is strengthened by the relationship and influence between the motivation and learning environment of students that are seen from the value of Sig under 0.025, which is 0.019 and has a contribution of $70.3 \%$. Implications and Recommendations: Based on the results obtained, the researcher recommends that students should be given an opportunity in learning, and the teacher must create a creative and innovative learning.
\end{abstract}

Keywords Learning Environment, Motivation, Students

\section{Introduction}

Education is all things in life that influence the formation of thinking and acting of an individual. Education is an endless process pursued by anyone, especially (as the responsibility) of the State. Therefore, it is governed by Law No. 20 of 2003 that education is used as an activity that can develop the potential of a student in thinking critically and creatively. Providing students with a maximum education will create quality students. As it is known, education is a process of acquiring and embedding skills performed by students [1]. Education in Indonesia is divided by several levels at one high school education level. In the level of higher education, the school learns various sciences, one of the sciences learned is natural science. Science is considered important to be taught as a separate subject because it provides knowledge for students. Science is a study of the natural, in this case related to the way of finding out about nature systematically so that science is not only the mastery of the knowledge group in the form of fact, concept, or principle only, but also a process of discovery, and science contains four things, content/products, methods, attitudes, and technology [2-3].

The attitudes that students have in the lesson greatly affect the students. When students have a positive attitude, then he will be earnest in the lesson, and vice versa [4]. Having a good attitude in a lesson then, will foster the motivation of a student to learn, and lead to the learning environment of a student. Being in a conducive and active learning environment will increase the motivation of a student in learning [5].

The environment is an important part and can't be separated with the things that are so in everyday life. The environment is the most important and fundamental part of human life, since the birth of mankind has been in a new and foreign environment to him [6-7]. Human nature and behavior is formed by itself. Learning environment in a conducive and quiet school can also be one of the factors affecting students ' interest in the physics lesson, such environment is needed because the physics lesson requires thoroughness and focus so that what students can be observed and understood, making it easier for students to achieve better learning outcomes. A conducive learning environment is the backbone and the driving factor that can provide its own attractiveness to the learning process, otherwise the less pleasant learning environment will cause saturation and boredom and ultimately will impede the student's spirit in learning [8-9]. Students who are passionate about learning will have a good impact on the 
learning outcomes he acquired.

Several studies in science education proved that motivation and self-regulatory ability are two important factors that determine students ' success in the learning process. Motivation plays an important role in providing energy, directing, and maintaining positive students' behaviour to always be actively involved in the learning process, and to influence the development of students' learning [10-12]. Students with high motivation for learning tend to have a positive attitude in learning [13], such as focusing on the learning process, which is actively involved in class activities, often filing teachers ' questions, and always having time to learn.

Physical environments can affect students' comfort and also their ability to learn to some extent [14]. A comfortable student tends to have a lot of questions compared to those who are uncomfortable. In addition, physical atmosphere can also affect the moral of learners [14]. In addition, physical atmosphere can also affect the attitudes of the learners. An unpleasant classroom environment can make students unenthusiastic and they become less willing to learn. Students' learning experience with a clean learning environment will produce a different and positive atmosphere for students [15]. Learning autonomy and active participation requires interaction with the environment and with others, which are also needed to develop leadership attitudes and abilities [16]. Thus, a clean and beautiful learning environment will produce comfort to the students and it also affects the student's motivation to a lesson.

Various research literature in the field of science education shows that the learning environment is a major factor that plays an important role in encouraging students to have high motivation [17]. So far, there has been a lot of research proving that constructivism-based learning environment focuses on students oriented student-centred learning to increase students' motivation in learning science [18-19]. A study conducted by Maison in 2019 shows that the task of orientation and investigation is a psychosocial factor in the learning environment that has the most positive and significant effect on learning motivation in learning physics [20]. However, there are limited studies in Indonesia to explore the psychosocial factors of the learning environment that have a significant impact on the students ' motivation in learning integrated science.

Therefore, to address the research gaps, the primary purpose of this study is to explore learning environments that have a significant impact on the learning motivation of students in the learning of integrated science. With the following research questions:

1. How is the student's learning environment in the science lesson?

2. How is the learning motivation that students have in the science lesson?

3. Is there a difference between class vii and class viii on the student learning environment?
4. Is there a difference between class vii and class viii on student motivation?

5. Is there an influence between the learning environment and the learning motivation of students?

\section{Materials and Methods}

\subsection{Research Design}

This research uses a mixed method approach, use of quantitative and qualified data in answering research questions and being part of a larger research program and designed as complement to provide [21]. Information related to different methodological approaches. The type used is sequential explanatory. Sequential Explanatory is a research that data collection initially is quantitative which is then followed by qualitative data, which means that the quantitative data is strengthened by the qualitative data to be acquired [22].

\subsection{Research Subject}

Where, quantitative data is obtained through the provision of motivation questionnaire and learning environment, then followed by qualitative activities that are conducting interviews with students. The study used 725 students in classes VII and VIII with details of 518 female students and 207 male students of MTS Madrasah who were equivalent to junior high school in Jambi city using purposive sampling. The purposive sampling is a sampling based on criteria that have been formulated previously by researchers [23], then interviews only 20 students who are willing to conduct interviews. Instruments in this study use questionnaires, and interviews. Questionnaire is a list of questions given to others who are willing to answer (respondents) according to the user's request [24].

\subsection{Research Instrument}

In the process of collecting the first data, because of using the sort of sequential explanation, the data obtained first is quantitative data through motivation Questionnaire and learning environment. Questionnaire learning environment adapted by [25] which has a valid declaration of 23 statements with the value of Cronbach Alpha of 0.73 , as well as the motivation to learn students obtained a valid declaration of 18 with value Cronbach Alpha amounted to 0.76 that uses Likert's scale for 4 , namely for a positive statement strongly disagree have a score of 1 , do not agree to have a score 2 , agree have a score 3 and strongly agree 4 then do a semi-structured interview to confirm the quantitative results that have been done. Then to process SPSS 21, data is used to search for descriptive statistics to see quantitative data, while for qualitative data using miles 
\& Huberman, i.e. data reduction, data display, and conclusion [26]. Descriptive statistics are presented in the frequency of summary, such as median, minimum, maximum, standard deviation, mean, and mode [24]. In this study the descriptive statistics used are mean, Min, Max, and Category.

Below is a category of the character of caring for the environment of students, among others, very not good, not good, good, and very good, like table 1 .
During data collection, the first activity that must be carried out is to select students based on the categories provided by the researcher, then questionnaire of learning environment and motivation has been given to students. Data was processed in SPSS 21 application to see descriptive statistics, in the form of, the mean, min, max, percentage, and category of students and see if there is an impact or comparison between the two variables.

Table 1. Categories of Motivation and Learning Environment

\begin{tabular}{|c|c|c|c|}
\hline \multirow{3}{*}{ Category } & \multicolumn{3}{|c|}{ Interval } \\
\hline & \multicolumn{2}{|c|}{ Learning Environment } & \multirow{2}{*}{ Motivation } \\
\hline & Teacher Support & Cooperation & \\
\hline Very Not Good & $12.0-21.0$ & $11.0-19.2$ & $18.0-31.5$ \\
\hline Not Good & $21.1-30.0$ & $19.3-27.5$ & $31.6-45.0$ \\
\hline Good & $30.1-39.0$ & $27.6-35.7$ & $45.1-58.5$ \\
\hline Very Good & $39.1-48.0$ & $35.8-44.0$ & $58.6-72.0$ \\
\hline
\end{tabular}

Questionnaire of Learning Environment and Motivation
Analysis of Questionnaire and Interviews Results

\section{Results}

Figure 1. Data Collection 


\subsection{Analyze Data}

All data were obtained from the motivation and learning environment questionnaires on students' values and collected and calculated and assisted with the SPSS 21 application. Descriptive statistics are given to calculate the frequency, percentage, mean, Min, and Max of a sample [22]. In this study, quantitative data was analyzed using parametric statistics of simple regression to determine whether there was an impact between students' learning environments and students' motivation, then see the difference between grade VII and VIII children in their learning environment and motivation This study used SPSS 21 at significance level 0.025 , and was followed by interviews that are used to reinforce quantitative data outcomes.

\section{Results}

Students' learning experience with a clean learning environment will produce a different and positive atmosphere for students. Children included in the class of students in the school will have limited direct experience in the environment [15]. So it will affect the motivation of students in learning. The novelty of this study is on the WIHIC learning environment only using 2 indicators, namely support teachers, and cooperation and motivation to learn students, and seeing the influence of the learning environment to the motivation of students.

\subsection{Teacher Support in Learning Environment}

The results of the questions given and the results obtained using the SPSS 21 application can be seen in the table 2 .

From table 2, which came from 725 respondents from the MTS in Kota Jambi, the results are obtained using the SPSS 21 application program, on the indicator of teachers' support in the student's learning environment, the dominant results are good, with a percentage of $69.4 \%$ for 503 students from a total of 725 students, very good at $19.1 \%$ for 138 students from a total of 725 students, not good $6.9 \%$ for 51 students from a total of 725 students, and very unwell amounting to $4.6 \%$ for 33 students from a total of 725 students. From 725 students, the mean result is 35.2, maximum value 45, and a minimum value of 19 .

The results of the survey analysis on table 2 , a teacher support indicator in the learning environment has a good teacher support of $69.4 \%$ (503 of 725) students in science lessons. This is demonstrated by the interaction between the teacher and the student and the teacher will discuss the lessons outside of the lesson hours. It can also be seen from the results of interviews that have been done.

"When you are struggling in learning, what do your teachers do?"

"My teacher gave support by motivating me, so I was able to work on it"

"When you find a problem in the lesson, but the lesson time has run out, what do you do?"

"I went to the teacher's loss and asked the teacher, and the teacher answered it and gave direction even though it was not the hour of learning"

Table 2. Results from teacher support indicators in the learning environment

\begin{tabular}{|c|c|c|c|c|c|c|c|c|}
\hline \multicolumn{5}{|c|}{ Classification } & \multirow{2}{*}{ Mean } & \multirow{2}{*}{ Min } & \multirow{2}{*}{ Max } & \multirow{2}{*}{$\%$} \\
\hline Range & Respond & M & $\mathrm{F}$ & Total & & & & \\
\hline $12.0-21.0$ & Not very good & 18 & 15 & 33 & \multirow{4}{*}{35.2} & \multirow{4}{*}{19} & \multirow{4}{*}{45} & 4.6 \\
\hline $21.1-30.0$ & Not good & 27 & 24 & 51 & & & & 6.9 \\
\hline $30.1-39.0$ & Good & 109 & 394 & 503 & & & & 69.4 \\
\hline $39.1-48.0$ & Very good & 53 & 85 & 138 & & & & 19.1 \\
\hline TOTAL & & 207 & 518 & 725 & & & & 100 \\
\hline
\end{tabular}




\subsection{Cooperation in the Learning Environment}

The results of the questions given and the results obtained using the SPSS 21 application can be seen in the table 3 .

Fram table 3, which came from 725 respondents from the MTS in Kota Jambi, the results are obtained using the SPSS 21 application program, on the indicators of cooperation in the student's learning environment, the dominant results are Well, with a percentage of $67.9 \%$ for 492 students from a total of 725 students, very well by $17.8 \%$ for 129 students of a total of 725 students, not good $8.4 \%$ for 61 students from a total of 725 students, and very unwell amounting to $5.9 \%$ for 43 students from a total of 725 students. From 725 students, the mean result is 31.5 , maximum value 41, and a minimum value of 17 .

The results of the analysis of questionnaires on table 3 , the indicators of cooperation in the learning environment have a good cooperation of $67.9 \%$ (492 of 725) students in science lessons. This is demonstrated by the good cooperation in the learning, both in the discussion of a group and outside the group. It can also be seen from the results of interviews that have been done.

"When you're doing group work, how respond of your bunch of friends?"

"We always interact and discuss topics that talk to the group we are discussing"

"When you are experiencing difficulties both in school and outside school, what do your classmates do?"

"My classmates always help me, whether I am struggling in school or outside school"

\subsection{Motivation}

The results of the questions given and the results obtained using the SPSS 21 application can be seen in the table 4.

From table 4, which came from 725 respondents from the Madrasah MTS in Kota Jambi the results obtained using the SPSS 21 application program, on learning motivation students have, the dominant result is good, with a percentage of $71.1 \%$ for 515 students from a total of 725 students, very good at $16.9 \%$ for 123 students from a total of 725 students, not good $7.1 \%$ for 51 students from a total of 725 students, and very unwell amounting to $4.9 \%$ for 36 students from a total of 725 students. From 725 students, the mean result is 53.5 , maximum value 71 , and a minimum value of 25

The result of the questionnaire analysis in table 4 is the motivation of students in learning, who have a good category of $71.1 \%$ (515 from 725 ) students on science lessons. This is demonstrated by the student's interest in learning and is characterized by more active students in class. It can also be seen from the results of interviews that have been done.

"How do you think the circumstances of friends are in class?"

"My friend on average has more interest in learning"

"What are the evidence, that your friends are more interested in the learning?"

"My friends are more active in the classroom, such as asking questions, answering questions, and always engaging in classes"

Table 3. Results of the cooperation indicators in the learning environment

\begin{tabular}{|c|c|c|c|c|c|c|c|c|}
\hline \multicolumn{5}{|c|}{ Classification } & \multirow{2}{*}{ Mean } & \multirow{2}{*}{ Min } & \multirow{2}{*}{ Max } & \multirow{2}{*}{$\%$} \\
\hline Range & Respond & M & $\mathrm{F}$ & Total & & & & \\
\hline $11.0-19.2$ & Not very good & 24 & 19 & 43 & \multirow{4}{*}{31.5} & \multirow{4}{*}{17} & \multirow{4}{*}{41} & 5.9 \\
\hline $19.3-27.5$ & Not good & 32 & 29 & 61 & & & & 8.4 \\
\hline $27.6-35.7$ & Good & 120 & 372 & 492 & & & & 67.9 \\
\hline $35.8-44.0$ & Very good & 31 & 98 & 129 & & & & 17.8 \\
\hline TOTAL & & 207 & 518 & 725 & & & & 100 \\
\hline
\end{tabular}

Table 4. The result of student learning motivation

\begin{tabular}{|c|c|c|c|c|c|c|c|c|}
\hline \multicolumn{5}{|c|}{ Classification } & \multirow{2}{*}{ Mean } & \multirow{2}{*}{ Min } & \multirow{2}{*}{$\operatorname{Max}$} & \multirow{2}{*}{$\%$} \\
\hline Range & Respond & $\mathrm{M}$ & $\mathrm{F}$ & Total & & & & \\
\hline $18.0-31.5$ & Not very good & 20 & 16 & 36 & \multirow{4}{*}{53.5} & \multirow{4}{*}{25} & \multirow{4}{*}{71} & 4.9 \\
\hline $31.6-45.0$ & Not good & 28 & 23 & 51 & & & & 7.1 \\
\hline $45.1-58.5$ & Good & 113 & 402 & 515 & & & & 71.1 \\
\hline $58.6-72.0$ & Very good & 46 & 77 & 123 & & & & 16.9 \\
\hline TOTAL & & 207 & 518 & 725 & & & & 100 \\
\hline
\end{tabular}




\subsection{Class VII and Class VIII Differences in Learning Environment}

To see the differences in the learning environment of students in classes VII and VIII can be seen in the table 5 .

Based on table 5, it can be seen the value obtained ( $t$ count) with the $\mathrm{T}$ table value. T-table values can be found in the $\mathrm{T}$ table with a significance value of 0.025 (2-tailed test) with a degree of freedom (df) 725. In this study, the results for the $\mathrm{T}$ table are 1.967903. Whereas the value of $\mathrm{T}$ is 22,453 . Where, testing the hypothesis there is no difference if $t$ arithmetic is smaller than $t$ table (Cramer, 2003). So it can be concluded that there are significant differences in the learning environment of students in Class VII and VIII.

\subsection{Class VII and Class VIII Differences in Student Motivation}

To see the student motivation differences in classes VII and VIII can be seen in the table 6 .

Based on table 6, it can be seen the value obtained ( $t$ count) with the $T$ table value. T-table values can be found in the $\mathrm{T}$ table with a significance value of 0.025 (2-tailed test) with a degree of freedom (df) 725 . In this study, the results for the $\mathrm{T}$ table are 1.967903. Whereas the value of $\mathrm{T}$ is 22.953. Where, testing the hypothesis there is no difference if $\mathrm{t}$ arithmetic is smaller than $\mathrm{t}$ table (Cramer, 2003). So it can be concluded that there are significant differences in students' motivation in Class VII and VIII.

Table 5. Independent Sample T-Test for learning environment

\begin{tabular}{|c|c|c|c|c|c|c|}
\hline & \multirow{2}{*}{$\mathrm{t}$} & \multirow{2}{*}{ df } & \multirow{2}{*}{ Mean } & \multirow{2}{*}{ Std.Deviation } & \multicolumn{2}{|c|}{$95 \%$ confidence interval } \\
\hline & & & & & Lower & Upper \\
\hline \multirow{2}{*}{ Learning Environment } & 22.453 & 725 & 3.0906 & .13321 & 18.236 & .6120 \\
\hline & 22.453 & 241.067 & 2.4033 & .19015 & 17.935 & .8615 \\
\hline
\end{tabular}

Table 6. Independent Sample T-Test for learning environment

\begin{tabular}{|c|c|c|c|c|c|c|}
\hline & \multirow{2}{*}{$\mathrm{t}$} & \multirow{2}{*}{ df } & \multirow{2}{*}{ Mean } & \multirow{2}{*}{ Std.Deviation } & \multicolumn{2}{|c|}{$95 \%$ confidence interval } \\
\hline & & & & & Lower & Upper \\
\hline \multirow{2}{*}{ Motivation } & 22.953 & 725 & 3.1306 & .13321 & 18.236 & .6120 \\
\hline & 22.953 & 251.067 & 2.2033 & .19015 & 17.935 & .8615 \\
\hline
\end{tabular}

Table 7. Results of Regression

\begin{tabular}{|c|c|c|c|c|c|}
\hline \multirow{2}{*}{ Variabel } & \multicolumn{2}{|c|}{ Unstandardized Coefficients } & Standardized Coefficients & t & sig. \\
\cline { 2 - 6 } & B & Std. Error & Beta & & \\
\hline 1 (Constant) & 14.361 & 3.151 & & 4.584 & .000 \\
\hline Learning Environment & .129 & .124 & .123 & 1.328 & .019 \\
\hline
\end{tabular}




\subsection{The Regression}

For the results of the influence of learning environment with students ' motivation can be seen in table 7 .

From table 7, it can be seen the results of a simple regression test found that the regression equation is $\mathrm{Y}=$ $14.361+0.129 \mathrm{X}$. for the number of contributions from learning environment on motivation can be seen in table 8 below.

Table 8. Contribution from learning environment on motivation

\begin{tabular}{|c|c|c|c|c|}
\hline Model & R & R square & $\begin{array}{c}\text { Adjust R } \\
\text { Square }\end{array}$ & $\begin{array}{c}\text { Std. Error of } \\
\text { the Estimate }\end{array}$ \\
\hline 1 & .813 & .703 & .702 & 2.703 \\
\hline
\end{tabular}

The result of simple regression analysis suggests that the value of the coefficient of determination is $\left(R^{2}\right) 0.703$. This means that the contribution from the learning environment to the motivation of learning is $70.3 \%$, while the remaining $28.4 \%$ is influenced by other variables.

\section{Discussion}

Designing a new learning environment that promotes deep learning has evolved during the 1990s [27]. A learning environment is a condition or condition around a student's learning environment that can affect students' learning processes and outcomes [28]. There are three main wards in learning, which are family, school and community [29]. According to Aini, if the condition of learning environment is very supportive, then students will be more enthusiastic in the learning process [30]. For example, the atmosphere is safe and comfortable so that students can absorb what their teachers teach and vice versa if environmental conditions lack support in the learning process, then students will feel uncomfortable in this impact on Attitudes of students. Therefore, the atmosphere of learning environment in school should be made as optimal as possible to support students feel comfortable like at home to learn. The atmosphere of students' learning environment certainly affects the attitude of students while learning. A learning process supported by good students' attitudes will run more effectively [31-32].

The environment is an important learning resource to the learning process and students' development. This means that the learning environment is a place of learning activities that affect students. The learning environment is a condition that affects the process of changing students ' behaviour to a better change in students' behavior [33-34]. This is because, students are the main purpose of self-study. With the atmosphere of a good learning environment, students will have the readiness and preparation to learn. The learning environment has a very important contribution in implementing learning, like complete facilities and supporting infrastructure that is able to facilitate education and its opposite. Environmental psychology plays an important role in humans' behavior, especially schools, because of this, continuous and structured care is given to students so that students are expected to change the expected behavior [35-36].

In this case, the learning environment in every school is good. One of the causes of learning in the classroom is from teachers. Because, prospective teachers are required to have a good pedagogical competence [37-40]. Teacher is one of the facilitators that affects the students ' satisfaction, attitude, achievement, diligence and builds a learning environment so that students can be active in decision-making, communication patterns, outcomes, diligence, content, and satisfaction [41-42]. If a teacher is motivated and positive, they will likely have a beneficial impact on their students as well. It is important for a teacher to understand this cause and effect to understand how to govern their class to create a better learning environment [43]. So a qualified teacher will create a good learning environment in class. With a conducive learning environment, it is possible for a student to learn well. "He thinks the motivation for learning arises because of intrinsic and extrinsic factors. One of the extrinsic factors influencing the motivation to learn is the conducive environment. Conducive learning environment can influence students' motivation. While the motivation to learn is an internal factor that affects students. Motivation plays a role in cultivating and directing learning activities.

Learning motivation can arise due to intrinsic and extrinsic factors, one of the extrinsic factors is a conducive learning environment. Conducive means truly supporting the sustainability of the learning process. The atmosphere during the learning process can affect the efficiency of learning time with a less conducive atmosphere that will make students not focused on the learning process so that the learning time is not effective [44-46]. In line with this, Hidi in 2000, explains that conducive environment is a driving factor that provides an appeal for the learning process, otherwise the less pleasant environment will cause saturation and boredom [47]. Teachers and parents who always provide a good example for a child, a social companion who provides positive life lessons, a quiet learning area, and a complete lesson tool can improve students ' motivation to learn.

Motivation is a series of businesses to provide certain conditions, so someone wants to do something. Motivation is an encouragement in one's self to try to make a better behavior change in fulfilling the need only [48]. In the learning activities, motivation is the driving force in the students that raises the learning activities, which guarantees the continuity of the learning activities and that gives direction to the learning activities, so that the objectives desired by the subject of study are accomplished [49-50]. That is, students who have strong motivation will have a lot of energy to do learning activities. Motivation will be aroused if the atmosphere of a good class, sufficient classroom, the existence of freedom to move, light and good air circulation will spur the motivation to learn students well according to ability [51]. This means that schools and classrooms need to be managed properly, and create a learning climate that supports learning. [52-53] states that the lack of motivation will lead to less-than-motivated students in learning. 


\section{Conclusions}

It can be seen that the outcome of the students' learning environment has a good category because, with the students having a good attitude in the learning environment, it will affect the motivation that is owned by the student. With students who have a good learning environment, it will encourage the extrinsic motivation of students, because the motivation of extrinsic students is the environment of the student. It is also supported by the relationship between the student's learning environment and the student's motivation and there is an influence between the two variables with a contribution of $70.3 \%$. According to the results, it is recommended that students need to be given the opportunity to conduct learning directly and teachers must perform innovative learning.

\section{Acknowledgements}

Thanks to the whole school principal who has given me permission to do research at his school. And all the teachers who helped during the study and all the respondents who had been willing to help me to be sampled in this study, I thank you as much as possible.

\section{REFERENCES}

[1] K. Wood. Education is Basic. New York: Taylor \& Francis Group, 2011.

[2] D. C, Giancoli, Physics: Principles and Applications of the 7th Edition of Volume 1. Jakarta: Erlangga. 2014

[3] Darmaji., Astalini., D. A, Kurniawan., H. Parasdila., Irdianti., Susbiyanto., M. Ikhlas., Kuswanto. E-Module Based Problem Solving in Basic Physics Practicum for Science Process Skills. International Journal of Online and Biomedical Engineering (IJOE), 15(15). 4-17, 2019

[4] Astalini, D. A. Kurniawan., Darmaji, L. R, Sholihah., R. Perdana. Characteristics of Students' Attitude to Physics in Muaro Jambi High School. Humanities \& Social Science Reviews (HSSR), 7(2), 91-99. 2019.

[5] S. B, Nolen. Learning Environment, Motivation, and Achievement in High School Science. Journal of Research in Science Teaching. 40(4), 347-368. 2003.

[6] A. Lizzio., K. Wilson., \& R. Simons. 'University students' perceptions of the learning environment and academic outcomes: implications for theory and practice'. Studies in Higher Education, 27(1), pp. 27-52. 2002

[7] M. A, Helou., V. Keiser., M. Feldman., S. Santen., J. W, Cyrus., \& M. S, Ryan. Student well-being and the learning environment. The Clinical Teacher, 16(4), 362-366. 2019 doi: $10.1111 /$ tct.13070

[8] C. R, Thrush., J. J, Spollen., S. G, Tariq., D. K, Williams., J. M, Shorey. Evidence for validity of a survey to measure the learning environment for professionalism. Med Teach 33, 683-688. 2011
[9] M. Meriläinen. Factors affecting study-related burnout among Finnish university students: teaching-learning environment, achievement motivation and the meaning of life. Quality in Higher Education, 20(3), 309-329. 2014. doi: 10.1080/13538322.2014.978136

[10] K. M, Law., S. Geng., \& T. Li, Student enrollment, motivation and learning performance in a blended learning environment: The mediating effects of social, teaching, and cognitive presence. Computers \& Education, 136, 1-12. 2019.

[11] T. Tasiwan., S. E, Nugroho., \& H. Hartono. Analisis Tingkat Motivasi Siswa Dalam Pembelajaran IPA Model Advance Organizer Berbasis Proyek. Jurnal Pendidikan IPA Indonesia, 3(1), 2014.

[12] S. Velayutham., J. Aldridge., \& E. Afari. Students' learning environment, motivation and self-regulation: A comparative structural equation modeling analysis. In Application of structural equation modeling in educational research and practice (pp. 115-133). Brill Sense. 2013.

[13] Maison, A., Kurniawan, D. A., \& Solihah, L. R. Deskripsi Sikap Siswa SMA Negeri Pada Mata Pelajaran Fisika. Edusains, 10(1), 160-167. 2018.

[14] Q. Suleman., \& I. Hussain. Effects of classroom physical environment on the academic achievement scores of secondary school students in kohat division, Pakistan. International Journal of Learning \& Development, 4(1), 71-82. 2014.

[15] B. Baidi. The role of parents' interests and attitudes in motivating them to homeschool their children. Journal of Social Studies Education Research, 10(1), 156-177. 2019.

[16] du Mérac, É.R. What we know about the impact of school and scouting on adolescents' value-based leadership. Journal of Educational, Cultural and Psychological Studies (ECPS Journal), 11(11), 207-224. 2015.

[17] M. Baeten., F. Dochy., \& K. Struyven. The effects of different learning environments on students' motivation for learning and their achievement. British Journal of Educational Psychology, 83(3), 484-501. 2013

[18] Putra, F., Nur Kholifah, I. Y., Subali, B., \& Rusilowati, A. (2018). 5E-Learning Cycle Strategy: Increasing Conceptual Understanding and Learning Motivation. Jurnal Ilmiah Pendidikan Fisika Al-Biruni, 7(2), 171.

[19] Rahayu, T., Syafril, S., Wati, W., \& Yuberti, Y. (2017). The Application of STAD-Cooperative Learning in Developing Integrated Science on Students Worksheet. Jurnal Ilmiah Pendidikan Fisika Al-Biruni, 6(2), 247-254.

[20] Maison., Syahrial., Syamsurizal., \& Tanti. Learning Environment, Students' Beliefs, And Self-Regulation in Learning Physics: Structural Equation Modeling. Journal of Baltic Science Education, 18(3), 389-403. 2019.

[21] D. M, Martens. Research and Evaluation in Education and Psychology Integrating Diversity with Quantitative, Qualitative, And Mixed Methods. Singapore: SAGE Publications Asia-Pacific 2010.

[22] J. W, Creswell. Research Design Qualitative, Quantitative, And Mixed Method Aproach. Singapore: SAGE Publications Asia-Pacific, 2012.

[23] F. N, Kerlinger. Foundations of behavioral research. Yogyakarta: Gadjah Mada, 2014. 
[24] L. Cohen., L. Manion., \& K. Morrison. Research Methods in Education: Routledge. 2007

[25] W. Wahyudi., \& D. F, Treagust. Science education in Indonesia: A classroom learning environment perspective. In Contemporary Approaches to Research On Learning Environments: Worldviews, 221-246. 2006.

[26] M. B, Miles., \& A. M, Huberman. Qualitative data analysis (2nd ed.). Thousand Oaks, CA: Sage. 1994

[27] C. Bereiter., \& M. Scardamalia. Surpassing ourselves. An inquiry into the nature and implications of expertise. Chicago: Open Court. 1993.

[28] Z. Nurastanti., F. Ismail., \& S. Sukirman. Pengaruh lingkungan belajar di sekolah terhadap hasil belajar siswa pada mata pelajaran fiqih kelas XI Madrasah Aliyah Negeri 1 Banyuasin. Jurnal PAI Raden Fatah, 1(1), 41-46. 2019.

[29] N. J, Entwistle., \& E. R, Peterson. 'Conceptions of learning and knowledge in higher education: relationships with study behaviour and influences of learning environments'. International Journal of Education, 41(6), pp. 407-28. 2004

[30] P. N, Aini., \& A. Taman. Pengaruh kemandirian belajar dan lingkungan belajar siswa terhadap prestasi belajar akuntansi siswa kelas XI IPS SMA negeri 1 sewon bantul tahun ajaran 2010/2011. Jurnal Pendidikan Akuntansi Indonesia, 10(1), 48-65. 2012.

[31] S. Sungur., \& S. Güngören. "The Role of Classroom Environment Perceptions in Self-Regulated Learning and Science Achievement." Elementary Education Online. 8: 883-900. 2009

[32] S. Sungur., \& B. Senler. "An Analysis of Turkish High School Students' Metacognition and Motivation." Educational Research and Evaluation. 15: 45-62. 2009

[33] K. Smit., C. J, de Brabander., \& R. L, Martens. Student-centred and teacher-centred learning environment in pre-vocational secondary education: Psychological needs, and motivation. Scandinavian Journal of Educational Research,

58(6), 695-712. 2013, https://doi.org/:10.1080/00313831.2 013.821090

[34] A. De Kock., P. Sleegers., \& M. J. M, Voeten. New learning and the classification of learning environments in secondary education. Review of Educational Research, 74, 141-170. 2004.

[35] J. S, Jukema., M. Veerman., J. Van Alphen., G. Visser., C. Smits., \& T. Kingma. Nurturing gerontology students' intrinsic motivation to cocreate: The design of a powerful learning environment. Gerontology \& Geriatrics Education, 1-10. 2017. https://doi.org/:10.1080/02701960.2017.13777 02

[36] P. H. M, Cremers., A. E. J, Wals., R. Wesselink., N. Nieveen. \& M. Mulder. Selfdirected lifelong learning in hybrid learning configurations. International Journal of Lifelong Education, 33(2), 207-232, 2014. https://doi.org/:10.1080/ 02601370.2013.838704

[37] Syahrial., Asrial., D. A, Kurniawan., P. Nugroho., R. Septiasari., R. A, Pratama., \& R. Perdana. Increased Behavior of Students' Attitudes to Cultural Values using the Inquiry Learning Model Assisted by Ethnoconstructivism. Journal of Educational Science and Technology. 5(2), 176-188. 2019.

[38] Asrial, Syahrial, D. A, Kurniawan., F. Chan., P. Nugroho., R.
A. Pratama., R. Septiasari. Identification: The Effect of Mathematical Competence On Pedagogic Competency of Prospective Teacher. Humanities \& Social Science Reviews (HSSR). 7(4), 85-92, 2019.

[39] Asrial., Syahrial., D. A, Kurniawan., M. Subandiyo., N. Amalina. Exploring obstacles in language learning among prospective primary school teacher. International Journal of Evaluation and Research in Education (IJERE), 8(2), 249-254. 2019.

[40] Asrial., Syahrial., D. A, Kurniawan., R. Perdana., P. Nugroho. Supporting Technologi 4.0: Ethnoconstructivist Multimedia for Elementary Schools. International Journal of Online and Biomedical Engineering (iJOE). 15(9), 4-15. 2019.

[41] C. T, Beer., \& G. G, Darkenwald. Gender differences in adult student perceptions of college classroom social environments. Adult Education Quarterly, 40(1), 33-42. 1989

[42] Maison., Astalini., D. A, Kurniawan., R. Perdana., \& L. Anggraini. The Phenomenon of Physicology Senior High School Education: Relationship of Students' Attitudes towards Physics, Learning Style, Motivation. Universal Journal of Educational Research. 7(10), 2199-2207. 2019.

[43] L. Hannah. The rise of the corporate economy. Routledge, 2013.

[44] S. Kingir., Y. Tas., G. Gok., \& S. S, Vural. Relationships among constructivist learning environment perceptions, motivational beliefs, self-regulation and science achievement. Research in Science \& Technological Education, 31(3), 205-226. 2013. https://doi.org/:10.1080/ 02635143.2013 .825594

[45] S. Velayutham., \& J. M. Aldridge. "Influence of Psychosocial Classroom Environment on students' Motivation and Self-Regulation in Science Learning: A Structural Equation Modeling Approach." Research in Science Education 43: 507-527. 2013

[46] M. Liu., D. Williams., \& S. Pedersen. Alien Rescue: A problem-based hypermedia learning environment for middle school science. Journal of Educational Technology Systems, 30(3), 255-270. 2002

[47] S. Hidi., \& J. M, Harackiewicz. Motivating the academically unmotivated: A critical issue for the 21st century. Review of Educational Research, 70(2), 151-179. 2000.

[48] D. Stipek. Motivation to learn: From theory to practice. Needham Heights, MA: Allyn \& Bacon. 1993

[49] S. L, Knight., \& H. C, Waxman. Investigating the effects of the classroom learning environment on students' motivation in social studies. Journal of Social Studies Research, 14, 1-12. 1990.

[50] M. Liu. The Effect of a Hypermedia Learning Environment on Middle School Students' Motivation, Attitude, and Science Knowledge. Computers in the Schools, 22(3-4), 159-171. 2005. https://doi.org/:10.1300/j025v22n03_13

[51] H. C, Waxman., \& S. Y. L, Huang. Motivation and Learning Environment Differences in Inner-City Middle School Students. The Journal of Educational Research, 90(2), 93102. 1996. https://doi.org/:10.1080/00220671.1996.994445 0

[52] Astalini., D. A. Kurniawan., U. Sulistiyo, U., R. Perdana., S. Susbiyanto. E-Assessment Motivation in Physics Subjects 
for Senior High School. International Journal of Online and Biomedical Engineering (iJOE). 15(9), 4-15. 2019.

[53] Maison., Ernawati, M. D. W., Budiarti, R. S., Kurniawan, W., Ningsih, Y., Puspitasari, T. O., Jannah, N., Putra, D. S. (2019). Learning in Nature Science: Social Implication, Normality of Scientist., Attitudes Towards Investigation of Natural Science, and Interest Adds to Science Learning Time. International Journal of Scientific \& Technology Research, 8(12), 1478-1484. 